\title{
Comparison of the skin surface temperature on the front of thigh after application of combined red-IR radiation and diadynamic currents executed in a different sequence
}

\author{
Ewa Boerner · Joanna Bauer · Magdalena Kuczkowska • \\ Halina Podbielska • Barbara Ratajczak
}

Received: 24 November 2014/Accepted: 5 February 2015/Published online: 4 March 2015

(C) The Author(s) 2015. This article is published with open access at Springerlink.com

\begin{abstract}
Most physical treatments have thermal effects. Effect of heat on the body is not always uniform and depends on the treated body surface, the intensity of the stimulus, the stimulus duration, changes in the intensity of the stimulus and the physical environment. Thermovision is a method that allows for precise determination of the temperature distribution of the tested body surface. The aim of the study was to evaluate the effect of sequence of execution of infrared irradiation combined with visible light, for simplicity called further IR and diadynamic currents (called further DD) on the distribution of skin surface temperature. We also evaluated whether the order of execution of physical treatments affects the consensual reaction and temperature variations depending on sex and body mass index. The study involved 28 volunteers -16 women and 12 men aged 19-28 years. The treatments were performed on the front of right thigh in two sequencesIR-DD and DD-IR. For measuring the temperature distribution, there was thermovision used. In each sequence, there were five images captured with the use of FLIR T335 camera. The significance of changes in skin temperature was rated with Student's $t$ test for dependent samples, whereas the dependence on the treatments sequence and sexual differentiation was analyzed with the use of test for independent samples, and the correlations were evaluated
\end{abstract}

E. Boerner $(\bowtie) \cdot$ M. Kuczkowska $\cdot$ H. Podbielska .

B. Ratajczak

Faculty of Physiotherapy, University School of Physical

Education, Al. Paderewskiego 35, 51-612 Wrocław, Poland

e-mail: ewa.boerner@awf.wroc.pl

J. Bauer · H. Podbielska

Department of Biomedical Engineering, Wrocław University of

Technology, Wybrzeże Wyspiańskiego 27, 50-370 Wrocław,

Poland by determining the Pearson's $r$ linear correlation coefficient. In the assessment of statistical significance, the critical threshold $\alpha=0.05$ was used. Regardless of the treatments sequence, the average surface temperature of the right thigh after IR radiation increased by more than $4{ }^{\circ} \mathrm{C}$. However, there were no significant temperature changes observed after the treatment with diadynamic currents. More dynamic changes in the average temperature values were stated in the sequence DD-IR, as $30 \mathrm{~min}$ after the second treatment, the temperature was higher as compared to the initial value by $1{ }^{\circ} \mathrm{C}$. Statistically significant sex-dependent differences occurred only after infrared radiation.

Keywords Thermal imaging - Visual red and nearinfrared light · Diadynamic currents

\section{Introduction}

Physical medicine is a discipline dealing with the clinical use of not only naturally occurring physical factors, but also those produced by different types of devices used in the field of prevention and diagnostics. The basis of therapeutic effect of physical factors on the human body is the ability of tissues to respond to the stimuli. The transfer of physical stimuli into the body is possible due to skin, namely due to its rich blood supply, innervation and numerous receptors. Most physical treatments have thermal effects. The effect of heat on the body is not always uniform and depends on the treated surface of the body, intensity of stimulus, stimulus duration, changes in the intensity of the stimulus and the physical environment [1-3].

The part of physical therapy, which makes use of therapeutic effect of thermal energy, is thermotherapy, 
which includes exposure to infrared radiation and visible (mostly far red) light. The biological effect of combined far red and near-infrared radiation with the wavelength in the range of $600-1500 \mathrm{~nm}$ raises tissue temperature due to the increased kinetic energy of the molecules. Under the influence of heat, there appear several effects: dilation of blood vessels, increased blood flow and lymph circulation, increased diffusion through the walls of capillaries and, consequently, speeding up the metabolism. Heat intensifies the process of removing the exudates from the inflamed tissues. Defense mechanisms of the body against infections are activated and the pain subsides. The muscles relax and the extensibility of the connective tissue are increased. Local heat may also act through reflex mechanisms on the functioning of other organs [4-7].

Another commonly prescribed medical treatment in physical therapy is electrotherapy, which uses therapeutic effects of electrical currents. Frequently used treatments include diadynamic (DD) currents, called also Bernard currents. These are low-frequency monophasic sinusoidal pulsed currents, up to $100 \mathrm{~Hz}$. In therapy with diadynamic currents, there are two components-direct current and sinusoidal current. Diadynamic currents have analgesic, strong congestive effect, and they improve trophics of tissues having altered excitability of muscle and tissue $\mathrm{pH}$. Vasodilation takes place on the way of selective stimulation of nerve endings in the autonomic nervous system responsible for vascular reactions under the influence of direct current. Better blood circulation speeds up the improvement of nutrition and metabolism, which plays an important role in the treatment of many diseases. Depending on the type of disease and the expected effect, the corresponding sequence and the type of DD current is used. The most commonly used order of treatments is: $\mathrm{DF}$ current min-2, CP min-3 and LP min-3, whereas the abbreviations used for these different currents relate to the original French terms: $\mathrm{DF}$-diphase fixe, $\mathrm{CP}$-courtes periods, LP-longues periodes [8-13].

Currently, one of the most commonly used methods for determining changes of skin surface temperature is thermovision, which uses the ability of human organism to emit far infrared radiation. Thermal images illustrate the distribution of superficial body temperature. Thermovision in medicine has been used for over 50 years. It is used as a diagnostic method or for evaluating the effects of treatment, among many others, in cardiology, oncology, dermatology, rheumatology, neurology, ophthalmology, dentistry and physiotherapy [14-18].

Thermovison is a noninvasive, noncontact procedure, safe for the tested person and the examiner. It can be used in people of all ages, regardless of sex or emotional state, as well as in pregnant women. Measurements can be performed repeatedly in a short period of time [19].
Physical treatments are often used in the medicine as analgesic and anti-inflammatory therapy. Physical stimulus should be adjusted in a way that it causes a specific response with the desired effect. The body's ability to respond to a physical stimulus depends on many factors, including age, sex, the nature and duration of disease or the type of medication. Thus, planning and dosage of treatments requires not only the knowledge of all the physiological and pathological conditions of the body's response to stimuli, but also systematical tracking of the response to them in the course of physical treatment. The issue that should be considered here is the use of polytherapy in the correct sequence. For instance, a method which increases the sensory threshold and the methods, which require defining the threshold by the patient cannot be applied together. The use of polytherapy is quite difficult because there is not enough information on the correct order of the treatments (some may act antagonistically or synergistically in relation to one another), breaks between them, dose selection, at the same time taking into account the individual characteristics such as sex, age and body mass index (BMI).

The aim of the study was to evaluate the effect of order of execution of infrared radiation combined with visible light IR and diadynamic currents DD on the distribution of surface temperature on the front surface of the right thigh. The other assessed questions concerned the problem whether and what consensual reaction occurred, depending on the sequence of performed procedures and whether sex and BMI have an effect on the temperature distribution after the performed treatments.

\section{Study material}

The study was conducted with the approval of the Senate Commission of Bioethics of the Wrocław University School of Physical Education, issued on March 19, 2012. Study group consisted of 28 volunteers (students) including 16 women and 12 men aged 19-28 years (Table 1).

Basic parameters of height and mass distribution of examined men and women are shown in Table 2.

On the basis of the height and body mass, the BMI of the subjects was calculated. The diversity of body mass indices is shown in Table 3 .

Table 1 Parameters of the age distribution in the study group

\begin{tabular}{lllll}
\hline Sex & \multicolumn{3}{l}{ Age/in years } & \\
\cline { 2 - 5 } & Mean & SD & Minimum & Maximum \\
\hline Women & 21.3 & 2.2 & 19 & 28 \\
Men & 20.6 & 1.2 & 19 & 23 \\
Total & 2.0 & 1.8 & 19 & 28 \\
\hline
\end{tabular}


Table 2 Height and body mass of examined subjects

\begin{tabular}{llrrrl}
\hline Feature & Sex & Mean & SD & Minimum & Maximum \\
\hline Height/cm & Women & 167.8 & 6.8 & 158 & 180 \\
& Men & 180.7 & 5.3 & 173 & 190 \\
Body mass/kg & Women & 60.6 & 7.0 & 47 & 70 \\
& Men & 73.7 & 10.7 & 55 & 89 \\
\hline
\end{tabular}

Table 3 BMI factor of subjects in the study group

\begin{tabular}{|c|c|c|c|c|}
\hline \multirow[t]{2}{*}{ Group } & \multicolumn{4}{|c|}{$\mathrm{BMI} / \mathrm{kg} / \mathrm{m}^{2}$} \\
\hline & Mean & $\mathrm{SD}$ & Minimum & Maximum \\
\hline Women & 21.6 & 2.6 & 18.1 & 26.7 \\
\hline Men & 22.5 & 3.0 & 18.4 & 27.5 \\
\hline Total & 22.0 & 2.8 & 18.1 & 27.5 \\
\hline
\end{tabular}

As depicted in tables, the study group was homogenous with respect to the age and BMI.

\section{Study methods}

The physiotherapeutic procedures were performed on each participant in the following order: first week (I): infrared radiation with visible light (IR) and after it, diadynamic currents-IR-DD sequence. In the second week (II): first diadynamic currents and then, infrared radiation with visible light-DD-IR sequence. The treatments were performed on the front surface of the right thigh $15 \mathrm{~cm}$ above the top of the patella and $10 \mathrm{~cm}$ below the groin.

$375 \mathrm{~W}$ Astar Lumina therapeutic lamp was used for light irradiation (near IR and red). Operating time was $15 \mathrm{~min}$, and the distance of the lamp from the surface of the treated area was $40 \mathrm{~cm}$. For the treatment with diadynamic currents, there was Jonoson apparatus from Physiomed used. The sequence and duration of the diadynamic currents were as follows: DF $2 \mathrm{~min}, \mathrm{CP} 3 \mathrm{~min}$ and LP 3 min. The intensity of the diadynamic currents was adjusted to the feelings of a treated person. In the electrotherapy, the electrical current intensity is adjusted to the personal feeling of the treated person that should not feel any unpleasant sensation, irritations or burnings, only some so-called "buzzing" or "tingling". The area of each electrode used for the procedure was $30 \mathrm{~cm}^{2}$. All physiotherapy treatments were performed by the same physiotherapeutist's, in accordance with generally accepted principles.

The study was conducted in a room temperature and a relative humidity between 35 and $40 \%$. Superficial body temperature distribution was studied with the use of a FLIR T335 thermal imaging camera. Immediately prior to the study, examined persons did not undergo any intense physical activity nor physical treatments. Each volunteer taking part in the experiment adapted to conditions of the surroundings for a period of $20 \mathrm{~min}$ with an exposed test area of the body. Thermal images were captured in the standing body position, facing the camera. The optical axis of the camera was perpendicular to the center of the tested area, whereas the distance from the participant to the front of the camera was constant and equal to $1.2 \mathrm{~m}$. First, five thermal images in the first week and then, five images in the second week of the study of each participant were recorded. The thermal images were stored on a computer disk in the form of files in JPG format with a size of $320 \times 240$ pixels. Then, they were subjected to computer analysis with the use of Therma CAM Researcher 2.9 software.

For the statistical description of the analyzed features, arithmetic mean values were used as a measure of the average value, whereas as a measure of the degree of differentiation of individual results-standard deviation. The description of the distribution was completed by determination of the variability of characteristics, i.e. the minimum and maximum values in the empirical distribution. The significance of changes of surface temperature of thighs was assessed using Student's $t$ test for dependent samples. The dependence of the sequence of applied treatments and gender differentiation was tested with the use of Student's $t$ test for independent samples. Correlations were analyzed by determining the Pearson's linear correlation coefficient $r$.

In the assessment of statistical significance, the critical threshold was at the level of $\alpha=0.05$. This means that the statistical significance was stated in the case, where $p$ significance level satisfied the inequality $p<0.05$. All calculations were performed with the use of STATISTICA10PL package.

\section{Results}

Thermal images allowed to determine the minimum, maximum and mean values of skin surface temperature on the anterior surface of both thighs of examined persons. Exemplary images of person No. 1, recorded before therapy $T_{0}$, after the first $T_{1}$ and second treatment $T_{2}$, and then $15 T_{3}$ and $30 \mathrm{~min} T_{4}$ after the whole procedure, are presented in Figs. 1 and 2. Thermal images depict the changes of superficial temperature distribution during the examined therapies sequences: IR-DD and DD-IR, correspondingly. The temperature values were examined in the rectangular region of interest ROI (on Figs. 1, 2 on right leg). Analogical ROI was chosen for the left leg. It is evident that the reaction to a physical agent lasted $30 \mathrm{~min}$ after the end of the therapy. One can see also the significant reaction on places, where the electrodes were attached to the body. 

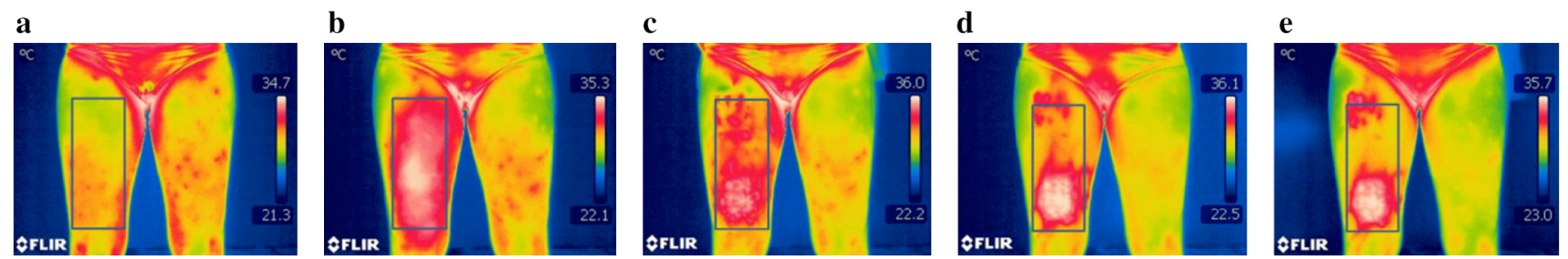

Fig. 1 Thermal images of person No. 1 after combined IR-DD treatment (week I): a before treatment $T_{0}, \mathbf{b}$ after the first treatment $T_{1}$, $\mathbf{c}$ after the second treatment $T_{2}$, d 15 min after the second treatment $T_{3}$, e 30 min after the second treatment $T_{4}$
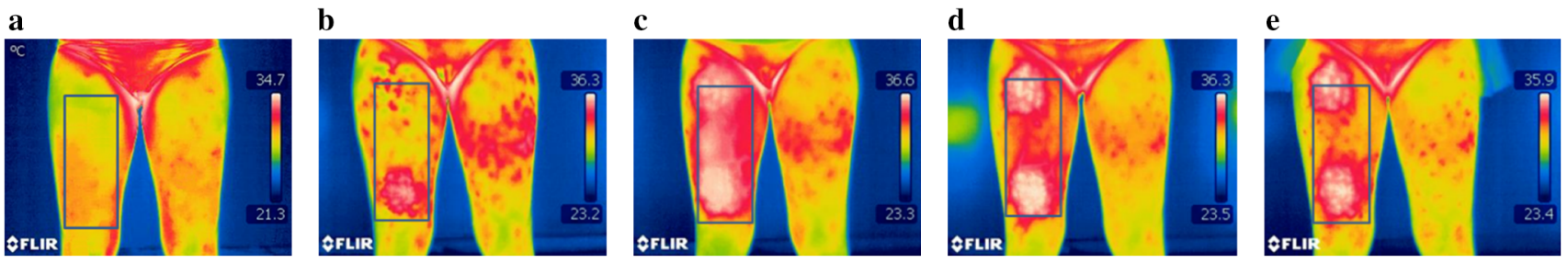

Fig. 2 Thermal images of person No. 1 after combined DD-IR treatment (week II): a before treatment $T_{0}, \mathbf{b}$ after the first treatment $T_{1}$, $\mathbf{c}$ after the second treatment $T_{2}, \mathbf{d} 15 \mathrm{~min}$ after the second treatment $T_{3}$, e 30 min after the second treatment $T_{4}$

The average initial temperature $T_{0}$ before treatment in the week I and II practically did not differ. The difference in the mean value was only $0.11^{\circ} \mathrm{C}$ and was not statistically significant, as shown in Table 4 . This proves that both tests were performed under the same controlled conditions.

IR radiation resulted in a significant increase in the surface temperature of the right thigh. When the procedure was performed as a first (IR-DD), the temperature has increased by an average of $4.3{ }^{\circ} \mathrm{C}$, whereas for the reverse sequence (DD-IR), only by $0.31{ }^{\circ} \mathrm{C}$ (Table 5). So, diadynamic currents only slightly changed the surface temperature of the right thigh. The average surface temperature increase just after the first treatment was significantly greater when the light therapy was applied as a first.

From the other hand, one can see that after the second treatment $T_{2}$, the temperature increase comparing to the initial one $T_{0}$ was $2,14{ }^{\circ} \mathrm{C}$ for the sequence IR-DD and $4.34{ }^{\circ} \mathrm{C}$ for the reverse sequence DD-IR. This effect was also visible after $15 \mathrm{~min}$ after the second treatment; however, it was not statistically significant. Therefore, if the therapeutist wants to achieve more warming just after the two combined procedures, the last one should be this one, which is causing more thermal effects (in our case IR). As depicted in Table 5, 30 min after the second treatment, this trend was further observed; however, the changes are not statistically significant, and the average temperature was only slightly higher than the initial one (by $<1{ }^{\circ} \mathrm{C}$ ).

The average temperature on the surface of both lower limbs before the treatments performed in IR-DD sequence was practically the same (difference of means was $0.03{ }^{\circ} \mathrm{C}$ ). After the light therapy, the temperature increased on both thighs, but was statistically significantly higher on the right thigh, only (Table 6). Immediately after the next treatment, namely-
Table 4 Surface temperature $T_{0}$ of the right thigh before treatments

\begin{tabular}{|c|c|c|c|c|c|c|}
\hline \multirow[t]{2}{*}{$\begin{array}{l}\text { Treatment } \\
\text { sequence }\end{array}$} & \multicolumn{4}{|c|}{ Temperature before treatments $/{ }^{\circ} \mathrm{C}$} & \multicolumn{2}{|c|}{$\begin{array}{l}\text { Student's } \\
t \text { test }\end{array}$} \\
\hline & Mean & SD & Minimum & Maximum & $t$ & $p$ \\
\hline $\begin{array}{l}\text { IR-DD } \\
\quad(\text { week I) }\end{array}$ & 30.33 & 1.31 & 27.4 & 32.9 & 0.458 & 0.6 \\
\hline $\begin{array}{l}\text { DD-IR } \\
\text { (week II) }\end{array}$ & 30.44 & 1.51 & 28.2 & 32.9 & & \\
\hline
\end{tabular}

diadynamic currents - the average temperature fell rapidly on the right limb, whereas a further decrease proceeded uniformly on both thighs, and the average temperature of the right thigh remained consistently higher (Table 6).

For DD-IR sequence, the initial average surface temperature of both thighs was the same (the difference was $\left.0.01{ }^{\circ} \mathrm{C}\right)$. After the application of diadynamic currents, left thigh's temperature has not changed, whereas after radiation, the temperature increased in both limbs. The cooling of the thighs surface was faster on the right leg. The average temperature on the surface of the left thigh was consistently significantly lower than on the right thigh, as shown in Table 7.

The data presented in Tables 6 and 7 confirmed the presence of consensual reaction, manifested in mutual correlation of surface temperature changes in both thighs. The stronger the correlation, the clearer the consensual reaction. Pearson's $r$ linear correlation coefficients of temperature changes relative to the initial temperature of the surface on the right and left leg are depicted in Table 8 . Stronger correlations, thus, clearer consensual reaction, occurred in the case of IR-DD sequence of treatments. 
Table 5 Comparison of temperature changes on the right thigh for different sequences of treatments

\begin{tabular}{|c|c|c|c|c|c|c|c|c|}
\hline \multirow[t]{2}{*}{ Measure } & \multirow{2}{*}{$\begin{array}{l}\text { Treatment } \\
\text { sequence }\end{array}$} & \multicolumn{4}{|c|}{ The difference with respect to the initial temperature $/{ }^{\circ} \mathrm{C}$} & \multirow{2}{*}{$\begin{array}{l}\text { Mean } \\
\text { difference } /{ }^{\circ} \mathrm{C}\end{array}$} & \multicolumn{2}{|c|}{ Student's $t$ test } \\
\hline & & Mean & SD & Minimum & Maximum & & $t$ & $p$ \\
\hline \multirow[t]{2}{*}{ After the first treatment $T_{1}$} & IR-DD & 4.30 & 1.36 & 1.6 & 7.1 & \multirow[t]{2}{*}{3.99} & \multirow[t]{2}{*}{15.44} & \multirow[t]{2}{*}{$<0.001$} \\
\hline & DD-IR & 0.31 & 0.49 & -0.6 & 1.2 & & & \\
\hline \multirow[t]{2}{*}{ After the second treatment $T_{2}$} & IR-DD & 2.14 & 0.91 & 0.3 & 3.8 & \multirow[t]{2}{*}{-2.19} & \multirow[t]{2}{*}{10.99} & \multirow[t]{2}{*}{$<0.001$} \\
\hline & DD-IR & 4.34 & 1.24 & 1.8 & 6.6 & & & \\
\hline \multirow[t]{2}{*}{15 min after the second treatment $T_{3}$} & IR-DD & 1.38 & 0.90 & 0.1 & 2.9 & \multirow[t]{2}{*}{-0.24} & \multirow[t]{2}{*}{0.09} & \multirow[t]{2}{*}{0.933} \\
\hline & DD-IR & 1.62 & 0.95 & -0.2 & 3.5 & & & \\
\hline \multirow[t]{2}{*}{30 min after the second treatment $T_{4}$} & IR-DD & 0.94 & 1.06 & -0.8 & 3.2 & \multirow[t]{2}{*}{0.15} & \multirow[t]{2}{*}{0.18} & \multirow[t]{2}{*}{0.861} \\
\hline & DD-IR & 0.79 & 0.87 & -0.8 & 2.3 & & & \\
\hline
\end{tabular}

Statistically significant values in bold

Table 6 Comparison of the average temperature on the surface of the right and left thighs, when performing procedures on the right limb in IRDD sequence

\begin{tabular}{|c|c|c|c|c|c|c|c|}
\hline \multirow[t]{2}{*}{ Measure } & \multirow[t]{2}{*}{ Thigh } & \multicolumn{4}{|c|}{ Temperature $/{ }^{\circ} \mathrm{C}$} & \multicolumn{2}{|c|}{ Student's $t$ test } \\
\hline & & Mean & SD & Minimum & Maximum & $t$ & $p$ \\
\hline \multirow[t]{2}{*}{ Before treatment $T_{0}$} & Left & 30.30 & 1.31 & 27.0 & 32.6 & \multirow[t]{2}{*}{0.642} & \multirow[t]{2}{*}{0.526} \\
\hline & Right & 30.33 & 1.31 & 27.4 & 32.9 & & \\
\hline \multirow[t]{2}{*}{ After the first treatment $T_{1}$} & Left & 32.07 & 0.94 & 29.3 & 33.7 & \multirow[t]{2}{*}{13.878} & \multirow[t]{2}{*}{$<0.00$} \\
\hline & Right & 34.63 & 0.67 & 33.2 & 36.0 & & \\
\hline \multirow[t]{2}{*}{ After the second treatment $T_{2}$} & Left & 31.09 & 0.97 & 28.5 & 32.9 & \multirow[t]{2}{*}{15.115} & \multirow[t]{2}{*}{$<0.00$} \\
\hline & Right & 32.47 & 0.85 & 31.1 & 34.2 & & \\
\hline \multirow[t]{2}{*}{$15 \mathrm{~min}$ after the second treatment $T_{3}$} & Left & 30.45 & 0.98 & 28.0 & 32.2 & \multirow[t]{2}{*}{14.527} & \multirow[t]{2}{*}{$<0.00$} \\
\hline & Right & 31.71 & 1.17 & 29.6 & 33.8 & & \\
\hline \multirow[t]{2}{*}{$30 \mathrm{~min}$ after the second treatment $T_{4}$} & Left & 30.19 & 1.11 & 27.6 & 32.1 & \multirow[t]{2}{*}{9.673} & \multirow[t]{2}{*}{$<0.001$} \\
\hline & Right & 31.27 & 1.36 & 28.7 & 33.7 & & \\
\hline
\end{tabular}

Statistically significant values in bold

Table 7 Comparison of the average surface temperature of the right and left thigh, when performing procedures on the right leg in DD-IR sequence

\begin{tabular}{|c|c|c|c|c|c|c|c|}
\hline \multirow[t]{2}{*}{ Measure } & \multirow[t]{2}{*}{ Thigh } & \multicolumn{4}{|c|}{ Temperature before treatments $/{ }^{\circ} \mathrm{C}$} & \multicolumn{2}{|c|}{ Student's $t$ test } \\
\hline & & Mean & SD & Minimum & Maximum & $t$ & $p$ \\
\hline \multirow[t]{2}{*}{ Before treatment $T_{0}$} & Left & 30.43 & 1.55 & 28.3 & 33.2 & \multirow[t]{2}{*}{0.223} & \multirow[t]{2}{*}{0.826} \\
\hline & Right & 30.44 & 1.51 & 28.2 & 32.9 & & \\
\hline \multirow[t]{2}{*}{ After the first treatment $T_{1}$} & Left & 30.43 & 1.41 & 28.2 & 33.1 & \multirow[t]{2}{*}{3.740} & \multirow[t]{2}{*}{0.001} \\
\hline & Right & 30.75 & 1.34 & 28.6 & 33.2 & & \\
\hline \multirow[t]{2}{*}{ After the second treatment $T_{2}$} & Left & 31.75 & 1.33 & 28.8 & 33.9 & \multirow[t]{2}{*}{16.945} & \multirow[t]{2}{*}{$<0.001$} \\
\hline & Right & 34.78 & 0.72 & 32.6 & 36.0 & & \\
\hline \multirow[t]{2}{*}{$15 \mathrm{~min}$ after the second treatment $T_{3}$} & Left & 30.57 & 1.35 & 28.3 & 32.9 & \multirow[t]{2}{*}{13.510} & \multirow[t]{2}{*}{$<0.001$} \\
\hline & Right & 32.06 & 1.30 & 29.4 & 34.2 & & \\
\hline \multirow[t]{2}{*}{$30 \mathrm{~min}$ after the second treatment $T_{4}$} & Left & 30.28 & 1.36 & 28.0 & 32.2 & \multirow[t]{2}{*}{10.528} & \multirow[t]{2}{*}{$<0.001$} \\
\hline & Right & 31.23 & 1.34 & 29.1 & 33.5 & & \\
\hline
\end{tabular}

Statistically significant values in bold 
Table 8 Comparison of Pearson's $r$ linear correlation coefficient of temperature changes on the right and left thigh for different sequences of treatments

\begin{tabular}{llll}
\hline Measure & \multicolumn{2}{l}{ Treatment sequence } & $p$ \\
\cline { 2 - 3 } & IR-DD & DD-IR & \\
\hline After the first treatment $T_{1}$ & 0.76 & 0.62 & 0.34 \\
After the second treatment $T_{2}$ & $\mathbf{0 . 8 7}$ & $\mathbf{0 . 6 8}$ & $\mathbf{0 . 0 8}$ \\
15 min after the second treatment $T_{3}$ & 0.84 & 0.76 & 0.43 \\
30 min after the second treatment $T_{4}$ & 0.81 & 0.80 & 0.92 \\
\hline
\end{tabular}

Statistically significant values in bold

It was also noticed that the average initial temperature of the surface of the right thigh was significantly higher in men than in women, as shown in Table 9. Most probably, it is due to the better musculature and thus vasculature in men and higher fat content (thermal isolator) in women.

Therefore, further analysis was devoted to the examination of temperature changes comparing to the initial values, depending on the gender. The study proved that these temperature differences were always higher in women than in men (Table 10). Statistically significant temperature increase was observed for IR-DD sequence after first and second treatment, as well as 15 min after the second treatment. For the sequence DD-IR, the statistically significant temperature change was stated after the second treatment. These data correspond to the changes observed for the entire group.

Next, the correlation of temperature changes on the right thigh comparing to the initial values and BMI indices, were examined. As it was expected, the Pearson's $r$ correlation coefficients were statistically insignificant, since the studied group was homogenous and exhibited similar reaction to the applied stimuli.

\section{Conclusions}

Very often after physical therapies, the changes of superficial temperature distribution are observed [1, 3, 15]. Despite the number of studies, it is not clear whether comparable results can be achieved concerning the temperature distribution after the execution of different treatments depending on the physical parameters such as the dose, duration and treatments sequence.

On the basis of the conducted study, it was found that the average surface temperature increased right after the first treatment and was significantly greater when the applied treatment was radiation (IR-DD sequence). However, immediately after both executed treatments, the average temperature was significantly higher for DD-IR sequence.

Table 9 Surface temperature of the right thigh before treatment in the group of women and men in IR-DD and DD-IR sequence

\begin{tabular}{|c|c|c|c|c|c|c|c|}
\hline \multirow[t]{2}{*}{ Treatment sequence } & \multirow[t]{2}{*}{ Gender } & \multicolumn{4}{|c|}{ Temperature before treatments $/{ }^{\circ} \mathrm{C}$} & \multicolumn{2}{|c|}{ Student's $t$ test } \\
\hline & & Mean & SD & Minimum & Maximum & $t$ & $p$ \\
\hline \multirow[t]{2}{*}{ IR-DD } & Women & 29.69 & 1.05 & 27.4 & 31.3 & 3.50 & 0.002 \\
\hline & Men & 31.17 & 1.17 & 29.0 & 32.9 & & \\
\hline \multirow[t]{2}{*}{ DD-IR } & Women & 29.73 & 1.33 & 28.2 & 32.6 & 3.37 & 0.002 \\
\hline & Men & 31.38 & 1.23 & 28.8 & 32.9 & & \\
\hline
\end{tabular}

Statistically significant values in bold

Table 10 Temperature changes on right thigh in women and men, depending on the applied treatments sequence

\begin{tabular}{|c|c|c|c|c|c|c|c|}
\hline \multirow[t]{2}{*}{ Treatment sequence } & \multirow[t]{2}{*}{ Measure } & \multicolumn{2}{|c|}{ Women } & \multicolumn{2}{|l|}{ Men } & \multicolumn{2}{|c|}{ Student's $t$ test } \\
\hline & & Mean & SD & Mean & SD & $t$ & $p$ \\
\hline \multirow[t]{4}{*}{ IR-DD } & After the first treatment $T_{1}$ & 4.80 & 1.32 & 3.63 & 1.13 & 2.454 & 0.021 \\
\hline & After the second treatment $T_{2}$ & 2.31 & 0.93 & 1.92 & 0.85 & 1.151 & 0.260 \\
\hline & 15 min after the second treatment $T_{3}$ & 1.55 & 0.84 & 1.16 & 0.96 & 1.148 & 0.262 \\
\hline & $30 \mathrm{~min}$ after the second treatment $T_{4}$ & 1.06 & 1.13 & 0.79 & 0.99 & 0.646 & 0.524 \\
\hline \multirow[t]{4}{*}{ DD-IR } & After the first treatment $T_{1}$ & 0.34 & 0.48 & 0.27 & 0.52 & 0.373 & 0.712 \\
\hline & After the second treatment $T_{2}$ & 4.79 & 1.10 & 3.73 & 1.18 & 2.467 & 0.021 \\
\hline & 15 min after the second treatment $T_{3}$ & 1.70 & 0.94 & 1.51 & 0.98 & 0.524 & 0.605 \\
\hline & $30 \mathrm{~min}$ after the second treatment $T_{4}$ & 0.86 & 0.77 & 0.70 & 1.01 & 0.484 & 0.632 \\
\hline
\end{tabular}

Statistically significant values in bold 
Regardless of the sequence of performed procedures on the right thigh, there was an increase in the surface temperature of the left thigh observed as a result of consensual reaction, which is often observed in course of physical therapy.

The study confirmed that there are gender-dependent differences in the average temperature between men and women. In general, a higher average temperature of the right thigh surface was observed in men what is caused by stronger vasculature and thinner subcutaneous adipose tissue. From the other hand, the average increase in reference to the initial temperature was higher in women, regardless of the sequence of performed procedures, denoting higher reactivity in this group. As expected, no correlation between temperature changes and BMI was stated, due to the small variation of this coefficient in the study group.

The application of polytherapy during the whole process of rehabilitation is a common practice. Kuciel-Lewandowska et al. [20] evaluated the effect of electrotherapy, laser and infrared radiation combined with visible light in the analgesic treatment of cervical spine, used either separately or in combined sets of treatments. The conducted studies have shown that an appropriate combination of selected physical treatments increased the analgesic effect and is better than the use of a single treatment.

To appropriately select physical treatments, it is important to take into account, apart from a diagnosed illness, many other factors such as age, sex, BMI, or concurrent diseases. When prescribing certain procedures, it should be remembered that some of them are primarily analgesic, anti-inflammatory or relaxant in their character. Physiotherapy treatments should be ordered and executed in such a way that it enables to obtain some kind of synergy of the implemented therapy.

Polytherapy or a combination of therapies that exploit various physical stimuli are often administered in daily practice. For example, Bauer and Wiecheć, on the basis of their own experiences, offer treatments by means of electrotherapy (interference, DD, TENS, etc.) and ultrasound executed at the same time or the simultaneous application of laser with a magnetic field or ultrasonic wave [21].

Advances in science and technology contribute to the development of physical medicine and the broadening the knowledge of the physiology and pathophysiology thus enabling better understanding of the mechanisms of interaction of physical factors and the possibility of their application in the prevention and therapy. In this respect, the thermovision plays a key role, offering quick evaluation of the effectiveness of a number of physiotherapy treatments. Using thermal imaging gives the possibility not only to verify the effectiveness, but also to develop credible recommendations concerning physiotherapy method, the dose, exposure time or treatments sequence [22-24].
Open Access This article is distributed under the terms of the Creative Commons Attribution License which permits any use, distribution, and reproduction in any medium, provided the original author(s) and the source are credited.

\section{References}

1. Straburzyński G, Straburzyńska-Lupa A. Medycyna Fizykalna. Warszawa: PZWL; 2000.

2. Mika T, Kasprzak W. Fizykoterapia. Warszawa: PZWL; 2004.

3. Rudzińska A, Witkoś J, Nowotny J. The local and remote changes of skin temperature after certain physical treatment. Fizjoterapia. 2004;12(4):27-37 (in Polish).

4. Ammer K. Temperature effects of thermotherapy determined by infrared measurements. Phys Med. 2004;20 (Suppl. I):64-6.

5. Rutkowski R, Straburzyńska-Lupa A, Korman P, Romanowski W, Gizińska M. Thermal effectiveness of different IR radiators employed in rheumatoid hand therapy as assessed by thermovisual examination. Photochem Photobiol. 2011;87(6):1442-6.

6. Stofft E, Vaupel P. Water-filtered infrared-A radiation versus fango-paraffin pack: temperature profiles upon loco-regional thermotherapy. Phys Rehab Kur Med. 1996;06(1):7-11.

7. Straburzyńska-Lupa A, Orlicki A, Świetlik Z. Badania porównawcze leczniczego działania podczerwieni $\mathrm{z}$ filtrem wodnym (Hydrosun) i bez (Sollux) u pacjentów z chorobą zwyrodnieniową stawów kolanowych. Fizjoter Pol. 2004;4(4):345-8.

8. Can FR, Tandoğan R, Yılmaz İ, Dolunay E, Erden Z. Rehabilitation of patellofemoral pain syndrome: TENS versus diadynamic current therapy for pain relief. Pain Clin. 2003;15(1):61-8.

9. Carvalho AR, de Fungueto EM, Canzi IM, Barbiero C, Moraes V, Bertolini GRF, Aragao FA. Bernard's diadynamic currents and iontophoresis in low back pain treatment. Fisioterapia em Movimento. 2005;18(4):11-9.

10. Camargo BF, dos Santos MM, Liebano RE. Hypoalgesic effect of Bernard's diadynamic currents on healthly individuals. Rev Dor Sao Paulo. 2012;13(4):327-31.

11. Den Adel RV, Luykx RHJ. Low and medium Frequency Electrotherapy, Enraf-Nonius B.V. Rotterdam, December 2005.

12. Ratajczak B, Boerner E, Bieć E, Demidaś A, Kochański M. Porównanie mikroprądów i prądów diadynamicznych w leczeniu zespołów bólowych lędźwiowego odcinka kręgosłupa. Fizjoter. 2005;13(2):66-75.

13. Robertson V, Ward A, Low J, Reed A. Electrotherapy Explained, Principles and Practice. 4th ed. Amsterdam: Elsevier; 2006.

14. Śliwiński Z, Kufel W, Woszczak M, Śliwiński G, Lipińska A, Kiljański M. Temperatury powierzchni skóry w obrazie termowizyjnym po wybranych zabiegach fizykoterapeutycznych oraz porównanie skuteczności ich działania. Fizjoter Pol. 2009;9(4):321-31.

15. Ratajczak B, Boerner E, Demidaś A, Tomczyk K, Dębiec-Bąk A, Hawrylak A. Comparison of skin surface temperatures after ultrasounds with use of paraffin oil and ultrasounds with use of gel. J Therm Anal Calorim. 2012;109:387-93.

16. Prasał M, Sawicka KM, Wysokiński A. Termowizja jako metoda diagnostyczna stosowana w kardiologii. Kardiol Pol. 2010;9(68):1052-6.

17. Cholewka A, Drzazga Z, Sieroń A, Stanek A. Thermovision diagnostics in chosen spine diseases treated by whole body cryotherapy. J Therm Anal Calorim. 2010;102:113-9.

18. Cholewka A, Stanek A, Sieroń A, Drzazga Z. Thermography study of skin response due to whole-body cryotherapy. Skin Res Technol. 2012;18(2):180-7.

19. Ring EFJ. The historical development of thermometry and thermal imaging in medicine. J Med Eng Technol. 2006;30(4):192-8. 
20. Kuciel-Lewandowska J, Paprocka-Borowicz M, Jagudzka B, Kierzek A, Pozowski A, Ratajczak B, Boerner E. Ocena skuteczności wybranych zabiegów fizjoterapeutycznych w leczeniu bólu w przebiegu choroby zwyrodnieniowej kręgosłupa szyjnego. Acta Bio Opt Inform Med. 2012;18(3):194-9.

21. Bauer A, Wiecheć M. Terapie łączone. Systematyka i charakterystyka wybranych zabiegów. Fizjoterapia. 2013;35:18-29.

22. Golubnitschaja O. The message from the Secretary General of EPMA-European Association of Predictive, Preventive and Personalized Medicine. Acta Bio-Optica et Informatica Medica Inżynieria Biomedyczna. 2013;1(19):1-2.
23. Golubnitschaja O, Costigliola V. Common origin but individual outcomes: time for new guidelines in personalized healthcare. Pers Med. 2010;7:561-8.

24. Boerner E, Bauer J, Ratajczak B, Dereń E, Podbielska H. Application of thermovision for analysis of superficial temperature distribution changes after physiotherapy-comparison of infrared irradiation and cryotherapy. J Therm Anal Calorim. 2014; doi:10.1007/s10973-014-4026-6. 